\title{
Effect of variety and cutting interval on yield and proximate composition of alfalfa (Medicago sativa L.) under irrigation in Central Gondar zone, Ethiopia
}

Alemu Tarekegn Tiruneh ( $\sim$ mefetehiealemu@gmail.com )

Center for Research in Agricultural Genomics https://orcid.org/0000-0002-6262-5773

Dessalegn Gelaye Amsalu

ARARI: Amhara Regional Agricultural Research Institute

Kifetew Kesete Adane

ARARI: Amhara Regional Agricultural Research Institute

\section{Research Article}

Keywords: crude protein, dry matter yield, forage quality, harvest frequency

Posted Date: January 12th, 2022

DOI: https://doi.org/10.21203/rs.3.rs-1145324/v1

License: (c) (1) This work is licensed under a Creative Commons Attribution 4.0 International License.

Read Full License 


\section{Abstract \\ Background}

Understanding the relationship between dry matter yield production and forage quality throughout the growing season will help to optimize the cutting intervals between harvests in different Alfalfa (Medicago sativa L.) varieties. An experiment was conducted to assess the effects of harvest frequency on forage yield and quality of 2 improved cultivars (ILRI-6984 and var. DzF-552) of alfalfa (Medicago sativa L.) in Western Dembia district over 20 months during 2017 and 2018. Four harvest frequencies (every 30, 40, 50 and 60 days) were compared in a randomized complete block design (RCBD) with 4 replications. The experiment was laid down in a randomized complete block design (RCBD) in factorial arrangement with four replications. To assess their production potential plant height $(\mathrm{cm})$, number of branches per plant, fresh biomass yield $\left(\mathrm{t} \mathrm{ha}^{-1}\right)$ and dry matter yield $\left(\mathrm{t} \mathrm{ha}^{-1}\right)$ of the forge and its nutrient content were recorded. The data collected was subjected to analysis of variance (ANOVA) by using the general linear model (GLM) procedure in Statistical Analysis System (SAS) (2003) version 9.1.

\section{Results}

The results revealed that highest forage dry matter yield was recorded for variety ILRI-6984 harvested every 40 days (26.8 $\mathrm{t} \mathrm{DM} \mathrm{ha}^{-1}$ ) and for var. DzF-552 when harvested every 60 days (24.1 $\mathrm{t} \mathrm{DM} \mathrm{ha}^{-1}$ ) $(P<0.001)$. While crude protein concentration tended to decline as age at harvest increased, there was little consistency in the pattern. Crude protein yields were also inconsistent across treatments but ILRI6984 harvested every 40 days produced the highest yields $\left(6.5 \mathrm{t} \mathrm{ha}^{-1}\right)(\mathrm{P}<0.001)$.

\section{Conclusion}

These preliminary findings need to be confirmed under field conditions on a large scale along with longerterm studies to examine the longevity of the stands at these harvest frequencies. Irregular harvesting based on stage of maturity should be compared with fixed inter-harvest intervals.

\section{Background}

Growth patterns Feed shortage both in terms of quantity and quality is a crucial constraint for livestock production in Ethiopia, particularly in the study area, since priority is given to the production of food crops by both farmers and extension workers with little attention given to the livestock sector. Farmers are reluctant to devote land and labor to forage production. As a result of the severe feed shortage for livestock in the area during the long dry season, farmers are virtually completely dependent on crop residues, which are low in protein and digestibility, to supply fodder. 
To improve this situation more productive forages with better nutritional value are needed. Alfalfa (Medicago sativa) is well-known world-wide for its high CP

concentration and digestibility and is often considered 'The King or Queen' of forages by members of the dairy, beef and poultry industries [1]. This crop is normally grown under irrigation in many countries of the world and is harvested 5-7 times a year. Proper harvest management, e.g. cutting interval between harvests, is essential to obtain optimal alfalfa production, particularly in terms of forage quality and yield [2].

Although alfalfa is a very important forage crop, it is little known in the study area and we are unaware of any research to evaluate different alfalfa varieties and optimum cutting intervals between harvests in this environment. Since irrigation is available, this study was conducted to determine the performance of 2 new cultivars at 4 different harvest frequencies under irrigation.

\section{Methods}

\section{Description of the study area}

The study was conducted at Melkam wuha village of West Dembia district (120 17'42.18" N, 37o 13' $25.39 " \mathrm{E} ; 1,856 \mathrm{masl})$ for about 20 months. The soil texture of the study area is sandy loam with good water-holding capacity and the $0-40 \mathrm{~cm}$ horizon has on average $\mathrm{pH}$ of $7.5,3.96 \%$ organic matter, 6.4 ppm available $P$ and $2.16 \mathrm{cmol}(+) \mathrm{K} / \mathrm{kg}$ [3]. The area has a moist tropical climate and the mean monthly maximum temperature is $26.2^{\circ} \mathrm{C}$, while the mean monthly minimum temperature is $12.6^{\circ} \mathrm{C}$. Based on 10 year's (2008-2017) data, annual rainfall ranges between 665 and 1,524 mm (mean 1,095 mm). Rainfall during the study and medium-term data is shown in Figure 1.

\section{Experimental design, treatments and crop management}

Two improved alfalfa cultivars (ILRI-6984 and var. DzF-552) developed at International Livestock Research Institute (ILRI) were used for the experiment. Four harvest frequencies (every 30, 40, 50 and 60 days) were compared in a randomized complete block design with 4 replications. Plot size was $2.4 \times 2.8$ $\mathrm{m}$ with spacing of $40 \mathrm{~cm}$ between rows and $20 \mathrm{~cm}$ between plants within rows. To ensure effective establishment, N:P:S (19:38:7) fertilizer was applied at the rate of $100 \mathrm{~kg} \mathrm{ha}^{-1}$ at the time of planting. Sowing was done by hand-drilling into fully tilled soil in January 2016 and irrigation water was applied immediately after sowing, with a second irrigation after a further 7 days. After the emergence of seedlings, irrigation was applied through furrows at about 10-day intervals throughout the study. A total of 39 irrigations were applied for the entire study period (20 months) without measuring water amount. Two weeks after planting, seedlings were thinned to produce $20 \mathrm{~cm}$ plant spacing within rows. Weeding was done by hand on average every 2 months during the study, but more frequently at the beginning of the experiment. On the appropriate dates plants were harvested with a sickle at 5-7 cm above the soil surface. The first harvest was performed 60 days after planting for all treatments and subsequent 
harvests were done at the indicated harvest intervals for the respective treatments. At each harvest the green forage was weighed immediately and individual samples of alfalfa forage were taken and dried in a forced-draft oven at $65^{\circ} \mathrm{C}$ for 72 hours to determine dry matter concentration and for chemical analysis.

\section{Data collection}

In this experiment, after planting in the field their performance was evaluated with respect to plant height, number of branches per plant, fresh biomass yield $\left(\mathrm{t} \mathrm{ha}^{-1}\right)$, dry matter percent (DM\%) and Dry matter yield $\left(\mathrm{t} \mathrm{ha}^{-1}\right)$. Plant height was measured by averaging the natural standing height of ten plants per plot. Alfalfa forage harvested for herbage and dry matter yield were following each cutting interval. The main branch number was an average of primary branches on the stem of ten plants per plot.

\section{Forage quality analysis}

Chemical analyses of feeds were carried out by taking representative samples from different harvests. The feed samples were dried in forced air draft oven at $600 \mathrm{C}$ for $72 \mathrm{hrs}$ for partial dry matter (DM) determination. Dried samples of feeds were milled using laboratory mill to pass through $1 \mathrm{~mm}$ screen. Milled samples of feeds were taken to Debere Birhan Agricultural Research Centre and stored at room temperature pending chemical analysis. Dry matter (DM), crude protein (CP), and ash in the feed samples were determined according to the procedure of [4]. Nitrogen $(\mathrm{N})$ concentration was measured using the micro-Kjeldahl procedure [4] and crude protein (CP) was determined by multiplying $\mathrm{N}$ concentration by 6.25. Ash percentage was determined by placing a feed sample $(2 \mathrm{~g})$ in a temperature-controlled furnace heated to $600^{\circ} \mathrm{C}$ for 2 hours while, Organic matter (OM) was determined as 100 minus ash. Neutral detergent fiber (NDF), acid detergent fiber (ADF) and acid detergent lignin (ADL) were analyzed according to the procedures of [5].

\section{Data analysis}

The data collected were subjected to analysis of variance (ANOVA) by using the general linear model (GLM) procedure in Statistical Analysis System [6] version 9.1. When the difference was significant, an LSD (least significant difference) test at $5 \%$ probability level was used to locate differences between individual treatment means.

\section{Results}

\section{Biomass yield and related components}

For the full study period (20 months) dry matter yields (DMY) for the various treatments varied from 16.7 to $26.8 \mathrm{t} \mathrm{DM} \mathrm{ha}^{-1}$ with a mean of $20.5 \mathrm{t} \mathrm{DM} \mathrm{ha}^{-1}$ (Table 1$)$. There was a highly significant $(\mathrm{P}<0.001)$ interaction between variety and cutting interval in terms of green and dry biomass yield (Table 1). However there was no statistically significant $(p<0.05)$ interaction effect between variety and cutting interval on plant height $(\mathrm{cm})$, number of branches per plant and Dry matter percentage (Table 1). 
Table 1

Effects of variety and cutting interval on biomass yield, yield components and total crude protein production of alfalfa over 20 months in 2017 and 2018 growing seasons

\begin{tabular}{|c|c|c|c|c|c|c|}
\hline Treatment & $\begin{array}{l}\text { Plant } \\
\text { height } \\
\text { (cm) }\end{array}$ & $\begin{array}{l}\text { Number of } \\
\text { branches per } \\
\text { plant }\end{array}$ & $\begin{array}{l}\text { Green } \\
\text { Biomass } \\
\text { Yield }\left(t \mathrm{ha}^{-1}\right)\end{array}$ & $\begin{array}{l}\text { Dry matter } \\
\text { percentage }\end{array}$ & $\begin{array}{l}\text { Dry } \\
\text { biomass } \\
\text { yield ( } t \\
\left.\mathrm{ha}^{-1}\right)\end{array}$ & $\begin{array}{l}\text { Total CP } \\
\text { yield }(\mathrm{t} \\
\left.\mathrm{ha}^{-1}\right)\end{array}$ \\
\hline $\begin{array}{l}\text { ILRI- } \\
6984 * 30 \\
\text { DCl }\end{array}$ & 55.19 & 41.54 & $72.59^{b c}$ & 23.12 & $16.73^{c}$ & $3.9 c$ \\
\hline $\begin{array}{l}\text { ILRI- } \\
6984 * 40 \\
\mathrm{DCl}\end{array}$ & 56.24 & 43.94 & $106.80^{a}$ & 25.09 & $26.76^{a}$ & $6.5 a$ \\
\hline $\begin{array}{l}\text { ILRI- } \\
6984 * 50 \\
\mathrm{DCl}\end{array}$ & 58.16 & 48.63 & $75.32^{b c}$ & 25.82 & $19.42^{\mathrm{bc}}$ & $3.9 c$ \\
\hline $\begin{array}{l}\text { ILRI- } \\
6984 * 60 \\
\text { DCl }\end{array}$ & 53.66 & 52.11 & $74.30^{\mathrm{bc}}$ & 27.27 & $20.20^{b}$ & $4.3 b c$ \\
\hline $\begin{array}{l}\text { Var.DzF- } \\
552 * 30 \\
\text { DCl }\end{array}$ & 42.76 & 34.27 & $69.84^{c}$ & 25.82 & $17.65^{\mathrm{bc}}$ & $5.2 b$ \\
\hline $\begin{array}{l}\text { Var.DzF- } \\
552 * 40 \\
\mathrm{DCl}\end{array}$ & 45.22 & 34.12 & $71.44^{c}$ & 26.55 & $18.97^{\mathrm{bc}}$ & $3.6 c$ \\
\hline $\begin{array}{l}\text { Var.DzF- } \\
552 * 50 \\
\mathrm{DCl}\end{array}$ & 53.28 & 38.12 & $71.79^{c}$ & 27.67 & $19.83^{b}$ & $4.8 \mathrm{~b}$ \\
\hline $\begin{array}{l}\text { Var.DzF- } \\
552 * 60 \\
\mathrm{DCl}\end{array}$ & 56.35 & 40.02 & $83.19^{b}$ & 29.01 & $24.14^{\mathrm{a}}$ & $4.5 b c$ \\
\hline Mean & 52.61 & 41.59 & 78.16 & 26.29 & 20.46 & 4.6 \\
\hline CV (\%) & 12.92 & 5.89 & 9.64 & 3.86 & 9.32 & 12.03 \\
\hline $\begin{array}{l}\text { LSD } \\
(0.05)\end{array}$ & ns & ns & 11.08 & ns & 2.81 & 2.24 \\
\hline LS & ns & ns & $\star \star \star$ & ns & $\star \star \star$ & $\star \star \star *$ \\
\hline \multicolumn{7}{|c|}{$\begin{array}{l}* a-c \text { Means within columns having different superscript letters are significantly different at } * * *= \\
P<0.001 ; n s=\text { non-significant at }(P>0.05) \text { by LSD test. }\end{array}$} \\
\hline
\end{tabular}

Total crude protein production 
For the 20 months study period total CP produced $\left(\mathrm{t} \mathrm{ha}^{-1}\right)$ for the various treatments varied from 3.6 to $6.5 \mathrm{t} \mathrm{CP} \mathrm{ha}{ }^{-1}$ with a mean of $4.6 \mathrm{t} \mathrm{CP} \mathrm{ha-1} \mathrm{(Table} \mathrm{1).} \mathrm{The} \mathrm{highest} \mathrm{CP} \mathrm{yield} \mathrm{was} \mathrm{obtained} \mathrm{from} \mathrm{alfalfa}$ variety ILRI-6984 at a 40-day harvest interval and the lowest from var. DzF-552 at a 40-day harvest interval and ILRI-6984 harvested every 30 or 50 days $(P<0.001)$. The significant $(P<0.001)$ interaction between variety and harvest frequency in terms of crude protein production was of interest. While CP yield of ILRI-6984 was largely in line with DM yields since CP\% did not differ significantly between harvest frequencies, variation in CP\% for var. DzF-552 at different harvest frequencies meant that CP yield did not reflect DM yields.

\section{Forage quality}

There were differences in stage of maturity of alfalfa at the different harvest intervals, e.g. no flowering at 30-day intervals; $10 \%$ flowering at 40 -day intervals; $50 \%$ flowering at 50 -day intervals; and $90 \%$ flowering at 60-day intervals, with no marked differences between the 2 cultivars. The mean response for nutritive values to variety and cutting interval is shown in Table 2 . The interaction of Variety and cutting interval effect was significantly $(p<0.001)$ higher in crude protein production when Alfalfa variety ILRI- 6984 harvested at 40 days interval and when variety Var.DzF-552 harvested at 30 and 50 days interval. Therefore, crude protein concentration in harvested forage of ILRI-6984 varied from 20.5 to $24.2 \%$ $(P>0.05)$, while that for var. DzF-552 varied from 18.5 to $29.1 \%(P<0.05)$ (Table 2$)$. 
Table 2

The interaction effect of variety and cutting interval on proximate composition of alfalfa in 2017 and 2018 growing seasons

\begin{tabular}{|c|c|c|c|c|c|c|}
\hline \multirow[t]{2}{*}{ Treatment } & \multicolumn{6}{|c|}{ Chemical Composition of Feeds (\%) } \\
\hline & DM & Ash & $\mathrm{CP}$ & NDF & ADF & ADL \\
\hline ILRI- 6984*30 DCl & 91.00 & $12.01^{\mathrm{a}}$ & $23.32^{b c}$ & 57.76 & 39.58 & 9.82 \\
\hline ILRI- 6984*40 DCl & 91.67 & $12.00^{\mathrm{a}}$ & $24.18^{\mathrm{ab}}$ & 53.09 & 33.47 & 6.89 \\
\hline ILRI- 6984*50 DCl & 91.67 & $8.73^{\text {de }}$ & $20.48^{\mathrm{bc}}$ & 67.06 & 44.31 & 10.99 \\
\hline ILRI- 6984*60 DCl & 91.33 & $9.47^{\mathrm{cd}}$ & $21.38^{\mathrm{bc}}$ & 63.32 & 41.49 & 9.58 \\
\hline Var.DzF-552*30 DCl & 91.33 & $10.95^{\mathrm{ab}}$ & $29.10^{\mathrm{a}}$ & 51.39 & 31.37 & 6.56 \\
\hline Var.DzF-552*40 DCl & 91.67 & $10.91^{\mathrm{ab}}$ & $18.87^{b c}$ & 65.06 & 43.65 & 10.64 \\
\hline Var.DzF-552*50 DCl & 91.33 & $10.59^{\mathrm{bc}}$ & $24.22^{\mathrm{a}}$ & 61.03 & 37.25 & 9.03 \\
\hline Var.DzF-552*60 DCl & 91.33 & $8.00^{\mathrm{e}}$ & $18.50^{c}$ & 72.08 & 49.47 & 13.25 \\
\hline Mean & 91.46 & 10.34 & 22.37 & 61.35 & 40.07 & 9.60 \\
\hline CV (\%) & 1.06 & 6.98 & 4.37 & 13.47 & 9.30 & 19.59 \\
\hline LSD (0.05) & ns & 0.79 & 2.64 & ns & ns & ns \\
\hline LS & ns & $\star \star \star$ & * & ns & ns & ns \\
\hline \multicolumn{7}{|c|}{$\begin{array}{l}\text { *a-e Means within columns having different superscript letters are significantly different at } * * *= \\
P<0.001 ;{ }^{*}=P<0.05 ; \text { ns= non-significant at }(P>0.05) \text { by LSD test. }\end{array}$} \\
\hline \multicolumn{7}{|c|}{$\begin{array}{l}\mathrm{ADF}=\text { acid detergent fiber; } \mathrm{ADL}=\text { acid detergent lignin; } \mathrm{CP}=\text { crude protein; } \mathrm{CV}=\text { coefficient of variation; } \\
\mathrm{DCl}=\text { days cutting interval; } \mathrm{DM}=\text { dry matter; ILRI= international livestock research institute; } \mathrm{LS}=\text { level of } \\
\text { significant; } \mathrm{LSD}=\text { least significant difference; } \mathrm{NDF}=\text { neutral detergent fiber. }\end{array}$} \\
\hline
\end{tabular}

\section{Discussion}

\section{Biomass yield and related components}

Maximum green biomass yield $\left(\mathrm{t} \mathrm{ha}^{-1}\right)$ was recorded when Alfalfa variety ILRI- 6984 harvested within 40 days interval, while the lowest green biomass yield was recorded when Alfalfa variety Var.DzF-552 harvested at 30 days interval. For ILRI-6984 highest DMY occurred with a 40-day harvest interval and the lowest with a 30-day harvest interval, while for var. DzF-552 highest yield occurred at a 60-day harvest interval. With the exception of these 3 treatments, DMY did not vary between cutting frequencies or between cultivars (20.8 vs. 20.1 t DM ha $^{-1}$ ). 
This study suggests that harvesting of alfalfa ILRI-6984 at 40-day intervals in this environment will give maximum productivity in terms of both DM and CP yields of the forage, while delaying harvesting of var. DzF-552 until every 60 days gives the highest DM yields but not the highest CP yields. The data for ILRI6984 suggest that delaying harvesting beyond 40 days might result in dry matter loss through leaf fall with increasing maturity. These data were similar to those reported by [7] in Missouri, who reported that dry hay yields for cvv. Nimet and Alsancak peaked at 42-day harvest intervals. In contrast with this study, [8] reported dry biomass yield of $21.1 \mathrm{t} \mathrm{ha}^{-1}$ year $^{-1}$ from alfalfa cvv. FG-10-09(F), FG-9-09(F), Magna-801FG (F), Magna-788 and Hairy Peruvian, when harvested at 57-day intervals without compromising forage quality at Wargiba research site, Raya-Azebo district. [9] also reported a $21.0 \mathrm{t} \mathrm{ha}^{-1}$ year $^{-1}$ dry biomass yield from the same cultivars harvested every 45 days at Debre Zeit Agricultural Research Centre in East Shewa Zone of Oromia Regional State, Ethiopia. This could be due to differences in response of different cultivars to various cutting frequencies.

\section{Total crude protein production}

The most frequent harvesting produced lower DM yields than the least frequent harvesting but equal CP yields because of significantly higher $\mathrm{CP} \%$. Since forage must provide both energy and protein to livestock, the combination of high DM yield and high CP\% is ideal for forage. In contrast with the current results, [10] reported a $2.23 \mathrm{t} \mathrm{ha}^{-1}$ total CP yield when Berseem alfalfa was harvested every 30 days in Khartoum North (EL Selate project) in a farmer's field. This could be due to differences in alfalfa variety and cutting intervals used and also variations in agro-ecology and edaphic conditions in different locations.

\section{Forage quality}

The interaction of variety and cutting interval effect was not significant $(P>0.05)$ for dry matter (DM), neutral detergent fiber (NDF), acid detergent fiber (ADF) and acid detergent lignin (ADL) which is in agreement with the findings of [11] and in disparity with that of others [12]; [13]. Though not statically significant, all cultivars when harvested at 30,40, 50 and 60 days interval had greater than 91, 51, 31 and $6 \%$ dry matter (DM), neutral detergent fiber (NDF), acid detergent fiber (ADF) and acid detergent lignin $(A D L)$, respectively which agrees with the findings of [9].

Ash content was significantly $(\mathrm{p}<0.001)$ higher when alfalfa variety ILRI- 6984 and variety Var.DzF-552 harvested at 30 and 40 days interval. This might be due to much biomass produced and less organic matter accumulated to this stage for the two verities. This result was in accordance with the findings of [9] who reported the ash content of alfalfa variety FG10-09(F) when harvested at 45 days interval may reach at $10.47 \%$. The overall trend was for ash concentration in forage to decline with increasing age at harvest. This is not surprising as mineral concentrations in forage conventionally decline with increasing maturity.

Unlike ILRI-6984 a serious shattering of leaves followed by immediate regeneration was observed for var. DzF-552, which caused a serious reduction in CP\% when the variety was harvested every 40 and 60 days. 
$\mathrm{CP} \%$ for var. DzF-552 harvested every 30 or 50 days exceeded that of all other treatments except ILRI6984 harvested every 40 days. While normally CP\% of forage declines with increasing maturity [14]; [7], there was no consistent pattern of higher $\mathrm{CP} \%$ for more frequent harvests in this study. Overall, forage quality increased as cutting frequency optimized, which was consistent with other findings [7]; [14].

\section{Conclusion}

This study result suggests that alfalfa varieties ILRI-6984 harvested at 40-day intervals and var. DzF-552 harvested at 60-day intervals under irrigation provide high DM yields of high quality forage especially crud protein with low fiber content. Further studies are needed under wider field conditions to determine if these preliminary data are reflected in a commercial situation and importantly, what is the longevity of the stands under these cutting regimes. In some countries of the world, e.g. Australia, farmers harvest alfalfa at times reflecting stage of maturity of the plants, e.g. early flowering. This would vary with time of year and probably should be investigated relative to a predetermined inter-harvest interval.

\section{Abbreviations}

ADF: acid detergent fiber; ADL: acid detergent lignin; ANOVA: analysis of variance; $C P$ : crude protein; CV: coefficient of variation; DCl: days cutting interval; DM: dry matter; DMY: dry matter yield; ILRI: international livestock research institute; LS: level of significant; LSD: least significant difference; N: nitrogen; NDF: neutral detergent fiber; OM: organic matter.

\section{Declarations}

\section{Authors' contributions}

AT conceived the study and design, collected the data, performed the analysis on all samples, interpreted the data, wrote the manuscript and acted as cor-responding author. DA and KA assisted in collecting data and drafting of the manuscript. All authors read and approved the final manuscript.

\section{Author details}

\section{Acknowledgements}


The authors would like to thank Debre Berhan Agricultural Research Center for analyzing feed samples.

\section{Competing interests}

The authors declare that they have no competing interests.

\section{Availability of data and materials}

The authors want to declare that they can submit the data at whatever time based on your request. The data used for the current study are available from the corresponding author on reasonable request.

\section{Consent for publication}

Not applicable.

\section{Ethics approval and consent to participate}

Not applicable.

\section{Funding}

All authors dedicated their additional working hours to develop this paper with no specific grant from any funding agency.

\section{References}


1. USDA Census of Agriculture. 2012; http://www.agcensus.usda.gov/Publications/.

2. Brink G, Marten G. Harvest Management of Alfalfa-Nutrient Yield vs Forage Quality and Relationship to Persistence. Journal of Production Agriculture. 1989; 2:32-6. http://dx.doi.org/10.2134/jpa1989.0032.

3. Nigus D, Wondimu B, Sitot T, Feras Z, Rolf S. Current and residual effects of compost and inorganic fertilizer on wheat and soil chemical properties. Proceedings of the 7th Annual Regional conference on Completed Research Activities on Soil and Water Management, Bahir Dar, Ethiopia. 2016; 75-95.

4. AOAC (Association of Official Analytical Chemists). Official method of analysis. $15^{\text {th }}$ Edn. AOAC, Washington DC, USA. 2000.

5. Van Soest PJ, Robertson JB, Lewis BA. Methods for dietary fiber, neutral detergent fiber, and non-starch polysaccharides in relation to animal nutrition. Journal of Dairy Science. 1991; 74 (10): 3583-3597. doi: 10.3168/jds.S0022-0302(91)78551-2

6. SAS. SAS User's Guide: Statistics. Version 9.1.3. Statistical Analysis System Inc., Cary, NC, USA. 2003.

7. Kallenbach R, Nelson C, Coutts J. Yield, Quality, and Persistence of Grazing- and Hay-Type Alfalfa under Three Harvest Frequencies. Agronomy Journal. 2002; 94:1094-1103.

http://dx.doi.org/10.2134/agronj2002.1094.

8. Solomon W, Tesfay A. Evaluation of dry matter yield, yield components and nutritive value of selected alfalfa (Medicago sativa L.) cultivars grown under Lowland Raya Valley, Northern Ethiopia. African Journal of Agricultural Research. 2019; 14(15): 705-711. http://www.academicjournals.org/AJAR.

9. Mekuanint G, Ashenafi M, Diriba G. Biomass yield dynamics and nutritional quality of alfalfa (Medicago sativa) cultivars at Debre Zeit, Ethiopia. E3 Journal of Agricultural Research and Development. 2015; 5(2): 120-127. http://www.e3journals.org.

10. Azizza M, Babo F. Effect of Stage of Cutting Alfalfa (Berseem) on Crude Protein Content and Dry Matter Yield. ARPN Journal of Science and Technology. 2013; 3(10):982-985.

http://www.ejournalofscience.org.

11. Ji-shan C, Fen-lan T, Rui-fen Z, Chao G, Gui-li D, Yue-xue Z. Effects of cutting frequency on alfalfa yield and yield components in Songnen Plain, Northeast China. African Journal of Biotechnology. 2012; 11(21): 4782-4790. doi: 10.5897/AJB12.092.

12. Katić $S$, Mihailović $V$, Milić D, Karagić $Đ$, Glamočić $D$, Jajić I. Genetic and seasonal variations of fibre content in lucerne. Proceedings of the XXVIIth EUCARPIA Symposium on Improvement of Fodder Crops and Amenity Grasses, Copenhagen. 2008.

13. Diriba G, Mekonnen H, Ashenafi M, Adugna T. Biomass yield potential and nutritive value of selected Alfalfa (Medicago sativa.) cultivars grown under tepid to cool sub-moist agro-ecology of Ethiopia. E3 
Journal of Agricultural Research and Development. 2014; 4(1): 007-014. http://www.e3journals.org.

14. Moyer JR, Fraser J, Rode LM, Topinka AK. Effects of Growth Stage-Based Alfalfa Harvest on Weed Encroachment and Resultant Quality. Canadian Journal of Plant Science. 1999. 79: 243-247. http://dx.doi.org/10.4141/P98-059.

\section{Figures}

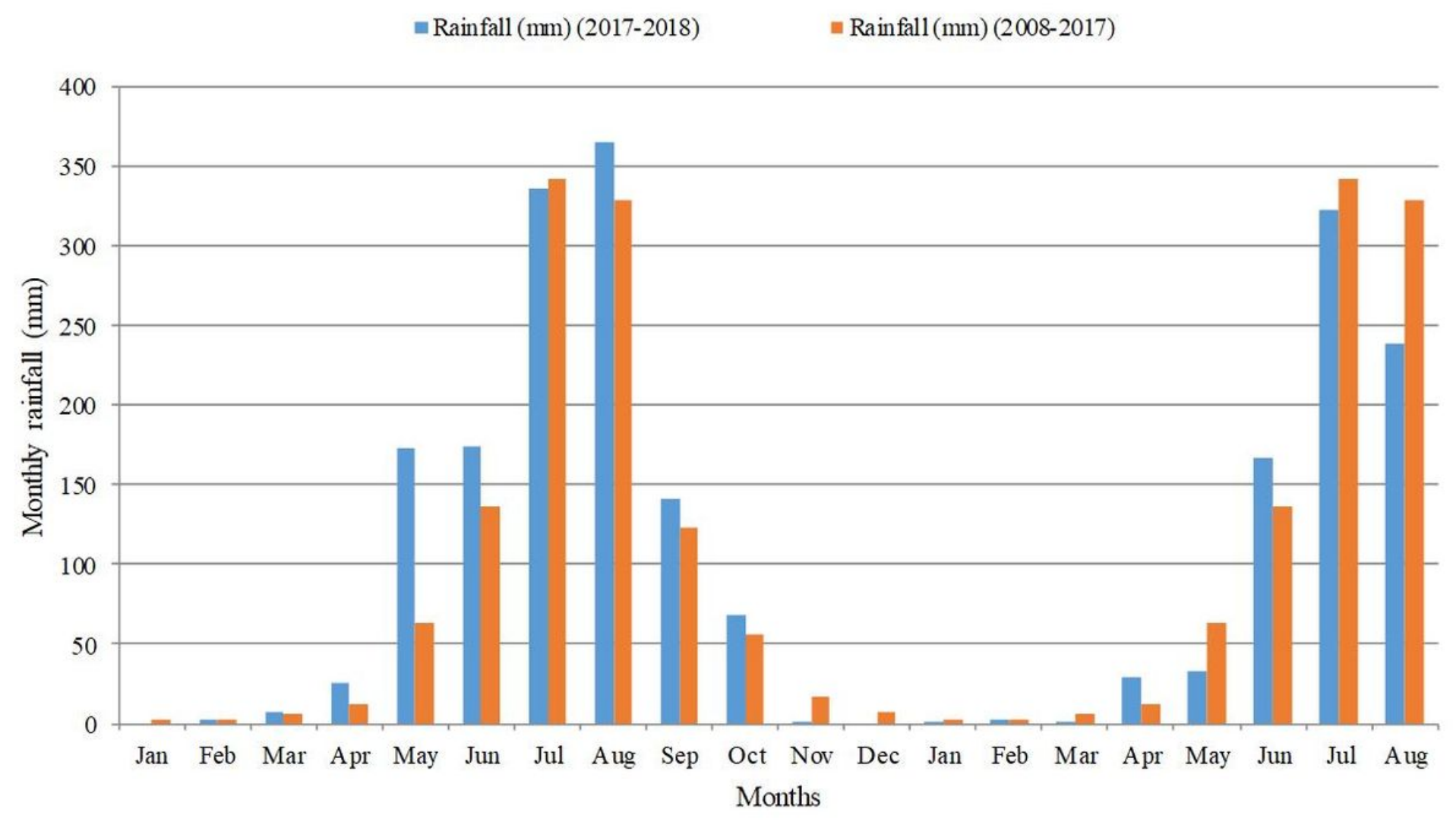

Figure 1

Monthly rainfall data over 10 years (2008-2017) representing the medium-term average and study period average (2017-2018) for the study area 